\title{
Seasonal patterns and related microclimatic drivers of soil inorganic nitrogen in an urban montane cloud forest
}

\section{Carlo Alberto Dominguez-Eusebio}

INECOL: Instituto de Ecologia

Oscar Luis Briones

INECOL: Instituto de Ecologia

Yareni Perroni ( $\nabla$ yperroni@uv.mx)

Universidad Veracruzana https://orcid.org/0000-0003-4607-821X

\section{Research Article}

Keywords: biogeochemistry, biometeorology, cloud forest, urban ecosystem, urban forest

Posted Date: April 14th, 2021

DOl: https://doi.org/10.21203/rs.3.rs-195268/v1

License: (c) (i) This work is licensed under a Creative Commons Attribution 4.0 International License.

Read Full License 


\section{Abstract}

Understanding the matter and energy dynamics in environments with strong human influence is essential since it allows us to know relevant ecological drivers in urban green land areas. It has been hypothesized that biogeochemical cycles in urban forests are more open (susceptible to nutrients soil losses) with respect to rural forests near cities. However, it is not clear if this ecosystem function occurs in the same way in systems from different latitudes. Soil nutrient dynamics and microclimatic conditions of an urban and a nearby rural montane cloud forest were registered from January 2016 to July 2017. Our objective was to compare edaphic and micro-climatic factors that drive soil inorganic $\mathrm{N}$ dynamics in these forests. Climate was slightly cooler and drier, and soil C, N, P and organic matter were lower in the urban than the rural forest. Seasonal soil inorganic $\mathrm{N}$ forms were related to above ground conditions in the urban forest, but to the belowground conditions in the rural forest. Consistently low $\mathrm{NH}_{4}: \mathrm{NO}_{3}$ ratio indicated high susceptibility to $\mathrm{N}$ soil loss in the urban forest. Our results support the hypothesis that urban cloud forests are functioning as open ecosystems in contrast to the rural forests.

\section{Introduction}

Nitrogen $(\mathrm{N})$ often limits primary productivity in natural terrestrial ecosystems, and it is more energetically costly to obtain and use than other nutrients (Vitousek and Howarth 1991; Gutschick 1981). In ecosystems $\mathrm{N}$ exists in different forms, including inorganic like ammonium $\left(\mathrm{NH}_{4}\right)$ and nitrate $\left(\mathrm{NO}_{3}\right)$ and organic like amino acids and nucleic acids. Inorganic $\mathrm{N}$ is directly available for plants and microorganism, but organic $\mathrm{N}$ must be mineralized. Biological $\mathrm{N}$ fixation is the main source of atmospheric income, and $\mathrm{NO}_{3}$ and gaseous losses are the main outputs for $\mathrm{N}$ in terrestrial ecosystems. However, anthropogenic activities present considerable additional sources that modify $\mathrm{N}$ inputs and outputs (Chapin et al. 2011). When outputs become too large, the ecosystems start to be "open" (susceptible to nutrients soil losses), and becomes a source of $\mathrm{N}$ and other elements (Chapin et al. 2011; Adler and Tanner 2013). An ecosystem is considered to be open when the outputs of nutrients and / or energy released are higher (e.g. nitrate solubilized in water or surface heat flux) than the inputs, and there is no return of the nutrients or energy to the ecosystem (towards vegetation or soil microbial biomass, etc.). On the contrary, an ecosystem is considered to be closed when matter and / or energy is constantly reused or cycled rather than lost (Lavelle and Berhe 2005; Schlesinger and Bernhardt 2013).

Since more than 4 billion inhabitants are currently located within cities around the world ( $55 \%$ of the world's population; World Bank 2020), and this is expected to increase in size, it is important to know the influence of human activity on ecosystem biogeochemistry and nutrient transformation processes (Kaye et al. 2006). Urban expansion could trigger environmental alterations that can affect some biogeochemical processes by incorporation of substances, particles and gases into the soil, mainly from fossil fuels burning and some solid, liquid and gaseous wastes (Grimm et al. 2008; Adler and Tanner 2003). Green areas within cities such as urban forests and parks can be directly affected through the modification of some stocks, flows, and processes of transformation of matter and energy in the soil (Pouyat et al. 2003; Adler and Tanner 2013). Little is known about the difference in the transport and 
transformation of matter and energy in soils of urban ecosystems, compared to natural ones and if models developed for natural environments significantly differ in urban environments (Kaye et al. 2006; Pavao-Suckerman 2008; Trammel et al. 2017). However, assumptions can be made based on natural models. Hypothetically, urban forests may have a loss of nutrients and changes in their productivity due to the fact that biogeochemical cycles may be more susceptible to opening-up, compared to natural ecosystems without, or little, human disturbance (Chapin et al. 2011). If the above is true and given the conditions in which urban forest soil develops, it is expected that urban ecosystems will present different strategies for nutrients conservation, compared to natural ecosystems. While research has been conducted on $\mathrm{N}$ cycling mechanisms in temperate urban forest soils (Pavao-Suckerman 2005; Kaye et al. 2006; Trammel et al. 2017), there is very little information on the functioning of green areas in other latitudes, and even less in regions of montane cloud forests. It should be noted that cloud forests are among the most biodiverse in the world but suffer a great threat from changes of coverage and land use (Bubb et al. 2004).

Comparing an urban forest to another with little human influence in terms of soil $\mathrm{N}$ conservation, would allow us to assess the intensity and importance of human activities on soil inorganic $\mathrm{N}$ dynamic. In addition, it would help us to identify the functioning of urban ecosystems compared to natural ecosystems and with this, recognize the potential of urban ecology to propose new theoretical models (Kaye et al. 2006).

The objectives of this work were to know the seasonal patterns of soil inorganic $\mathrm{N}$ forms of an urban cloud forest completely surrounded by a city and a nearby native cloud forest, and determine the edaphic and micro-climatic factors that drive soil inorganic $\mathrm{N}$ dynamics. The relationship $\mathrm{NH}_{4}: \mathrm{NO}_{3}$ will provide information about the nutritional state of the soil, potential energy stored, and movements of $\mathrm{N}$ in the ecosystem taking into account the low solubilization and high conserved energy of ammonium $\left(\mathrm{NH}_{4}\right)$ as a reduced form of $\mathrm{N}$ in contrast with nitrate $\left(\mathrm{NO}_{3}\right)$ as an oxidized form of $\mathrm{N}$ (Robertson and Groffman 2007; Abbasi et al. 2017; Recous et al. 1990; Hughes et al. 2004: Emmett 2007). Higher nitrate concentrations have been reported for urban environments in contrast to rural areas in other temperate zones, (Goldman et al. 1995; Raciti et al. 2011; Zhu et al. 2006; Enloe et al. 2015; Enloe 2014). If the differences in the potential of energy stored and movements of $\mathrm{N}$ between temperate urban and rural temperate forest are similar in warmer ecosystems, we hypothesized that the relation $\mathrm{NH}_{4}: \mathrm{NO}_{3}$ will be lower in the urban than in rural cloud forest.

\section{Materials And Methods}

\section{Study site}

Two sampling sites were established. The predominant vegetation corresponds to elements of the tropical montane cloud forest within the central mountainous area of the Gulf of Mexico, but under conditions of different human influence (Fig. 1). The Cerro de Macuiltépetl Ecological Park (19$32{ }^{\prime} 51.26 " \mathrm{~N}$ and $96-55^{\prime} 12.66 " \mathrm{~W} ; 1560 \mathrm{~m}$ asl) is a 30 ha fragment of cloud forest under protection for 
more than 40 years and completely surrounded by the city of Xalapa, Veracruz, Mexico (Government of the State of Veracruz 2020). The city has about 600 thousand inhabitants and the ecological park vegetation is typical of the cloud forest, with tree species such as Oreopanax xalapensis, Clethra mexicana, Quercus xalapensis, Turpinia insignis, Liquidamabar macrophylla, Liquidambar styraciflua, Citharexylum mocinnii, Carpinus Carolinian, Eugenia xalapensis, Miconia glaberrima, among others (Castillo-Campos 1991).

The average annual temperature in the city of Xalapa is $18.6^{\circ} \mathrm{C}$, with an average annual maximum and minimum of $27.4^{\circ} \mathrm{C}$ in May and $10.4^{\circ} \mathrm{C}$ in January, respectively. The average annual rainfall is 1433 $\mathrm{mm}$, with June being the wettest month with $275.4 \mathrm{~mm}$ and December the driest with $37.1 \mathrm{~mm}$ (SMN 2020). Around the city of Xalapa there are sugarcane crops, coffee trees and secondary forests of conifers and oaks (Allan-Ellis and Martínez-Bello 2010; CONABIO 2020).

The sampled rural forest has very little human activity and is located in the private area called El Riscal $\left(19-28^{\prime} 54.04 " \mathrm{~N}, 96-59^{\prime} 44.80\right.$ "W to $1570 \mathrm{~m}$ asl), $10 \mathrm{~km}$ in straight line from the urban forest. Given the relative short distance between the sampled sites and the same altitude, both forests are influenced by the same regional climatic frontal systems in winter and tropical systems in summer (Ruiz-Barradas et al. 2010). The rural forest presents typical cloud forest vegetation with a larger forest area compared to the urban forest. Dominant species in both sites are Liquidambar styraciflua, Quercus xalapensis, $Q$. leiophylla, Q. germana, Clethra mexicana, Turpinia insignis, Cinnamomum effusum, Carpinus caroliniana and Oreopanax xalapensis, and shrub species such as Ocotea psychotrioides, Miconia glaberrima, Palicourea padifolia and Eugenia xalapensis.

\section{Soil sampling and analysis}

Soil collections were made by composite samples taken by triplicate on a plot of $1 \mathrm{~m}^{2}$ at a depth of 15 $\mathrm{cm}(\mathrm{n}=13$ plots with composite samples were obtained, distributed in an area of $2.8 \mathrm{ha})$ at each study site, urban and rural. Soil collections were obtained seven times during the period between January 2016 and June 2017. The soil was stored in black bags at $4^{\circ} \mathrm{C}$ for further analysis in the Water and Soil Laboratory of the Institute of Ecology approximately 24 hours after sampling.

\section{Micro-climatic variables}

In each plot the surface floor (T0) and $15 \mathrm{~cm}$ deep (T15) temperatures were measured, as well as the depth of the litter found above them. At one point located in the center of each study site, an automatic weather station (Davis Instruments, USA) was installed at a height of $5 \mathrm{~m}$ above the ground with which temperature (Tair) and relative air humidity $(\mathrm{RH})$ were recorded every 15 minutes during the sampling season (January 2016-June 2017). Solar radiation (Rad), dew point temperature (Td), precipitation (Rain) and potential evapotranspiration (ETo) were also obtained.

We used the meteorological data between 10:00 and 15:00 hours since it was the time during which sample collection and measurements of the edaphic variables were made. The VPD was quantified by the difference between the saturation vapor pressure (es) and the current vapor pressure (e). The es was 
calculated using the Equation of Clausius-Clapeyron and $e$ was obtained through the relationship of $\mathrm{RH}$ to es (Borgnakke and Sonntag 2013).

\section{Edaphic variables}

To determine the soil inorganic N concentration, we used the method of Maynard and Kalra (1993), obtaining the ammonium concentration $\left(\mathrm{NH}_{4}\right)$ by shaking the sample with $\mathrm{KCl} 2.0 \mathrm{~N}$. Nitrate $\left(\mathrm{NO}_{3}\right)$ was extracted with the same extract as ammonium because it is soluble in water. Concentration of $\mathrm{NH}_{4}$ was determined by selective ion electrodes, and $\mathrm{NO}_{3}$ by capillary electrophoresis. Concentration of soil inorganic $\mathrm{N}$ (SINC) was determined by the sum of $\mathrm{NH}_{4}$ and $\mathrm{NO}_{3}$. The available phosphorus was determined in a fresh soil solution (P-Bray) by extracting it with a mixed solution of ammonium fluoride $(\mathrm{NH} 4 \mathrm{~F} 0.03 \mathrm{~N}$ ) and $\mathrm{HCl} 0.025 \mathrm{M}$ (Bray and Kurtz 1945). In the case of total P, digestion was performed with nitric and perchloric acid, while the quantification was performed with the vanadomolibdate reagent and the determination was performed on a visible light spectrum photometer (Model Spectronic 21.D). Soil $\mathrm{pH}$ was measured in a solution 1:5 with water. Soil water content (SWC) was obtained gravimetrically from the relationship between wet soil weight loss and dry weight. Total $\mathrm{C}$ and $\mathrm{N}$ concentration were determined through complete combustion in a Truspec analyzer (Leco, St. Joseph, MI). Organic C and organic matter were quantified with the Walkley and Black technique (Sollins et al. 1999). Inorganic carbon was calculated as the difference between total soil carbon and total organic carbon. The concentration of total sulfur in soil was determined with the turbidimetric method (Standard Methods For the Examination of Water and Wastewater, 4500-SO42 - SULFATE 2017).

\section{Data analysis}

To explore whether the amount of soil inorganic $\mathrm{N}$ and environmental microclimatic conditions are modified by the seasonality and urbanization of the cloud forest, we preformed an ANOVA model with a split-plot design (Montgomery 2013), forest as a two level factor (urban and rural forest) as the main plots, and seasonality as a seven level factor (months of sampling) as subplots. Multiple regressions were performed to determine the relations of soil $\mathrm{N}$ concentration (ammonium and nitrate) with edaphic and microclimatic variables. Variables such as $\mathrm{NO}_{3}, \mathrm{NH}_{4}$ and SINC were square root transformed to satisfy normality criteria. Adequate minimum models were reported for the significant variables evaluated (Crawley 2013). All statistical analyses were performed with R version 3.6.1 (R Core Team 2020). The alpha value for all cases was 0.05 .

\section{Results}

\section{Edaphic and microclimatic variables}

Soil of rural cloud forest showed significantly higher total C, N and P concentrations, soil organic matter and organic $\mathrm{C}$, inorganic $\mathrm{N}$ and $\mathrm{NH}_{4}$ and was more acidic than the urban forest (Table 1). On the other hand, soil of the urban forest showed higher concentrations of $\mathrm{NO}_{3}, \mathrm{P}-\mathrm{Bray}$, and $\mathrm{S}$ total. 
Table 1

Mean (standard deviation) values of micro-climate and soil variables from January 2016 to June 2017.

\begin{tabular}{|llll|}
\hline Soil variable & Urban Forest & Rural Forest & P value \\
\hline $\mathrm{NH}_{4}(\mathrm{mg} / \mathrm{kg})$ & $10.8(9.4)$ & $38.4(33.4)$ & $<0.001$ \\
\hline $\mathrm{NO}_{3}(\mathrm{mg} / \mathrm{kg})$ & $28.3(21.2)$ & $20.1(19.2)$ & $<0.001$ \\
\hline Soil Inorganic N (mg/kg) & $39.1(24.1)$ & $57.3(34.5)$ & $<0.001$ \\
\hline P-Bray (mg/kg) & $2.4(2.6)$ & $0.6(0.9)$ & $<0.001$ \\
\hline Total P (mg/kg) & $504.9(159.8)$ & $721.9(137.5)$ & 0.01 \\
\hline Total C (\%) & $6.9(1.2)$ & $16.1(2.7)$ & $<0.001$ \\
\hline Total N (\%) & $0.9(0.1)$ & $1.56(0.2)$ & $<0.001$ \\
\hline Total S (\%) & $1.8(0.3)$ & $1.3(0.1)$ & $<0.001$ \\
\hline Soil Organic Matter (\%) & $11.4(1.8)$ & $23.5(3.9)$ & $<0.001$ \\
\hline Organic C (\%) & $6.6(1.1)$ & $13.63(2.3)$ & $<0.001$ \\
\hline Micro-climatic variable & & & $<$ \\
\hline 15 cm Soil Temperature (C) & $16.7(2.7)$ & $17.9(2.7)$ & $<0.001$ \\
\hline Surface Soil Temperature (C) & $18(2.7)$ & $18.5(2.7)$ & 0.004 \\
\hline Soil Water Content (\%) & $33(5.9)$ & $51.4(5.5)$ & $<0.001$ \\
\hline pH & $5.8(0.6)$ & $4.5(0.6)$ & $<0.001$ \\
\hline Air Temperature (C) & $19.7(2)$ & $21.4(2.6)$ & $<0.001$ \\
\hline Dew Point Temperature (C) & $13.1(2)$ & $16.5(2.3)$ & $<0.001$ \\
\hline Accumulated Precipitation (mm) & 1665 & 1688 & - \\
\hline Accumulated Potential Evapotranspiration (mm) & 632 & 573 & - \\
\hline Solar Radiation (W/m ${ }^{2}$ ) & $529.9(103.5)$ & $486.2(160.7)$ & 0.15 \\
\hline Relative Humidity (\%) & $57.9(5.9)$ & $65.7(5.5)$ & $<0.001$ \\
\hline Water pressure (hPa) & $15.2(1.6)$ & $19(2.3)$ & $<0.001$ \\
\hline Saturated Water Pressure (hPa) & $25.7(3.8)$ & $6.5(1.7)$ & $<0.001$ \\
\hline Vapor Pressure Deficit (hPa) & $7.4 .6)$ & 0.001 \\
\hline
\end{tabular}

Precipitation was not significantly different between forests (Fig. 2). However, urban forest showed greater solar radiation, potential evapotranspiration and pressure vapor deficit but lower air and soil 
temperature than rural forest (Table 1). The SWC did not show marked seasonal differences but the urban forest showed the lowest mean SWC compared to the rural forest (Fig. 2). The water output (evapotranspiration) and VPD from the urban forest were greater than in the rural forest, with higher values in the rainy season, in June (Fig. 3). The annual soil temperature at surface and at $15 \mathrm{~cm}$ depth showed the highest and lowest values in summer and winter, respectively, with a mean difference of $1^{\circ} \mathrm{C}$ at the surface and $0.5^{\circ} \mathrm{C}$ at $15 \mathrm{~cm}$ of depth (Fig. 4).

\section{Soil inorganic $\mathbf{N}$ concentration}

The urban forest was lower in SINC compared to the rural one (Table 1). The predominant form of $\mathrm{N}$ was $\mathrm{NH}_{4}$ in the rural forest, twice what was found of $\mathrm{NO}_{3}$ (Table 1). On the other hand, urban forest had higher concentration of $\mathrm{NO}_{3}$ compared with $\mathrm{NH}_{4}$ concentration. Throughout the year, in the urban and rural forest the behavior of $\mathrm{N}$ available forms follows a pattern with high values in the warm and rainy season (summer) and low values in the dry and cold winter season, (Fig. 5). The maximum and minimum values of $\mathrm{NH}_{4}$ in the urban forest were 17.12 and $3.9 \mathrm{mg} \mathrm{N} / \mathrm{kg}$ respectively, while those of $\mathrm{NO}_{3}$ were 40.49 and $4.9 \mathrm{mg} \mathrm{N} / \mathrm{kg}$. In the rural forest the highest $\mathrm{NH}_{4}$ value was $79.94 \mathrm{mg} \mathrm{N} / \mathrm{kg}$, while the minimum was 11.69 $\mathrm{mg} \mathrm{N} / \mathrm{kg}$. On the other hand, at this same site, maximum and minimum $\mathrm{NO}_{3}$ values were $29.3 \mathrm{mg} \mathrm{N} / \mathrm{kg}$ and $7.23 \mathrm{mg} \mathrm{N} / \mathrm{kg}$, respectively.

Concentrations of soil $\mathrm{NO}_{3}$ and $\mathrm{NH}_{4}$ in the rural forest were significantly related to soil temperature at 15 $\mathrm{cm}$ depth (Table 2). The $\mathrm{NH}_{4}$ and SINC in rural forest showed a significant relationship only with the temperature below soil (Table 2, Fig. 6). In the urban forest the relationships were different to the rural forest since SINC and $\mathrm{NO}_{3}$ were significantly related to TO and VPD, while $\mathrm{NH}_{4}$ was significantly related only to $e\left(\mathrm{R}^{2}=0.27\right.$; Table 2 , Fig. 7$)$.

Table 2. Multiple regressions for ratios to soil $\mathrm{N}$ concentration and soil and/or micro-climate variables that were significant $(p<0.05$. SINC $=$ Soil Inorganic $N$ concentration, $T 15=$ Soil temperature at $15 \mathrm{~cm}$ depth, $\mathrm{T0}=$ Soil surface temperature, VPD $=$ Water vapor deficit, $\mathrm{e}=$ Water vapor pressure 


\begin{tabular}{c|lccc}
\multicolumn{1}{c|}{ Study site } & \multicolumn{1}{|c}{ Regression } & $\boldsymbol{R}^{2}$ & \multicolumn{1}{c}{$\boldsymbol{P}$} \\
\hline \multirow{3}{*}{ Rural forest } & $\mathrm{NO}_{3}=-32.2276+3.0517^{*} T 15-0.2653^{*} N H_{4}$ & 0.19 & $<0.001$ \\
& $\sqrt{N H 4}=-4.9219+0.5798^{*} T 15$ & 0.26 & $<0.001$ \\
& $\sqrt{S I N C}=-3.8129+0.6145^{*} T 15$ & 0.45 & $<0.001$ \\
& $\sqrt{N O 3}=-2.7742+0.2447^{*} T 0+0.4371^{*} V P D$ & 0.30 & $<0.001$ \\
& $N$ rban forest & $N H_{4}=-35.2852+3.025^{*} e$ & 0.27 & $<0.001$ \\
& $\sqrt{S I N C}=-3.0174+0.0387^{*} T 0+0.4525^{*} V P D$ & 0.43 & $<0.001$
\end{tabular}

The behavior of $\mathrm{N}$ concentrations $\left(\mathrm{NO}_{3}, \mathrm{NH}_{4}\right.$, and $\left.\mathrm{SINC}\right)$ in relation to edaphic and microclimatic variables is shown in Figs. 6 and 7. The increase in SINC was directly related to soil temperature at 15 of depth in the rural forest (Fig. 6); however, soil inorganic $\mathrm{N}$ concentrations in the urban forest increased with the increment with surface soil temperature and VPD (Fig. 7).

\section{$\mathrm{NH}_{4}: \mathrm{NO}_{3}$ ratio}

The urban forest showed lower $\mathrm{NH}_{4}: \mathrm{NO}_{3}$ ratio than the rural forest and both forests showed significant ( $F$ $=3.078, p=0.007$ ) seasonal variations during the year (Fig. 8). The rural forest presented minimum and maximum $\mathrm{NH}_{4}: \mathrm{NO}_{3}$ ratio values in February and March and in June and August, respectively. The maximum $\mathrm{NH}_{4}: \mathrm{NO}_{3}$ ratio values of the rural forest coincided with the rainy and warm season (summer season). As for the urban forest, the seasonal pattern of the $\mathrm{NH}_{4}: \mathrm{NO}_{3}$ ratio values was similar to that of the rural forest, but with significant differences between forests $(p<0.001)$, showing minimum values in March and February, and maximum values in June, with a peak in January 2016. The extreme peak of the $\mathrm{NH}_{4}: \mathrm{NO}_{3}$ ratio in January coincides with the coldest and driest month of the period evaluated in the urban forest.

\section{Discussion}

\section{Edaphic and micro-climatic conditions between forests and soil inorganic $\mathbf{N}$ dynamics}

Inorganic forms of $\mathrm{N}$ in the rural forest were related to below ground conditions whereas above ground conditions seem to drive soil inorganic $\mathrm{N}$ dynamics in the urban forest. Although soil ammonium is the 
main substrate for nitrate formation by autotrophic or heterotrophic nitrification processes (Robertson and Groffman 2007), very little is known about the microclimatic and edaphic conditions of this process.

Our hypothesis was supported, $\mathrm{N}$ inorganic forms differ between forests, the rural forest showed the highest ammonium concentration, while the urban forest showed the highest nitrate concentration. Thus, the urban forest showed a low potential of energy stored and potentially the highest movements of $\mathrm{N}$ in the ecosystem, in contrast to the rural forest. Edaphic and micro-climatic conditions associated with the dynamics of inorganic $\mathrm{N}$ between forests suggest that heterotrophic nitrifiers predominated in rural forests, while autotrophic nitrifiers predominated in urban forests.

\section{Rural forest}

Rural forest conditions were characterized by higher soil $\mathrm{C}$ and $\mathrm{N}$ concentration and lower soil $\mathrm{pH}$ compared to the urban forest. Although the existence of nitrification in acid soils (as was founded in the rural forest) has been recorded, little is known about its physiological bases (Robertson and Groffman 2007). A high potential net $C$ and $N$ mineralization rate (Dominguez-Eusebio et al. under review), and higher soil $\mathrm{C}$ in contrast to the urban forest suggests that heterotroph nitrifiers are carrying out the nitrification process in the rural forest using $\mathrm{C}$ as energy source, although further research must be done to confirm this hypothesis. Commonly, autotrophic nitrifiers carry out the nitrification process in the soil, but they are relatively poor competitors for ammonium when there is great abundance of heterotrophic microbes in the soil community (Robertson and Groffman 2007).

Nitrate and ammonium association with soil temperature at $15 \mathrm{~cm}$ deep in the rural forest can be explained not only because the temperature is an important driver of microbial activity including the nitrificant community (Bardgett 2005; Robertson and Groffman 2007; Smith et al. 2015), but also due to the fact that temperature drives $\mathrm{N}$ mineralization and immobilization processes in the soil (Robertson and Groffman 2007). A greater capacity for retention of radiative energy associated with a lower albedo, and lowest $\mathrm{N}$ microbial immobilization compared to the urban forest have been reported in a previous study (Dominguez-Eusebio et al. under review). Nutritional needs of the microbial community in the rural forest could be supported by inputs of organic substrates with low $\mathrm{C}: \mathrm{N}$ ratio, allowing the increase of ammonium and nitrate in the soil solution produced by $\mathrm{N}$ mineralization of the organic substrates (Robertson and Groffman 2007). Ammonium may be related to soil $\mathrm{N}$ conservation because it has greater energy storage capacity, is less soluble in water, with less potential to be lost by leaching compared with nitrate.

\section{Urban forest}

The urban forest showed lower concentrations of $\mathrm{C}$ and $\mathrm{N}$ in the soil than the rural forest. Also, lower potential net $\mathrm{C}$ and $\mathrm{N}$ mineralization rate, but greater potential net $\mathrm{N}$ microbial immobilization and net nitrification have been recorded in the urban forest in comparison with the rural forest (DominguezEusebio et al. under review). The positive association between nitrate concentration and surface temperature in the soil of the urban forest could indicate that the main nitrifier activity may be taking 
place at the soil superficial level. According to our results, increases in soil surface temperature in the urban forest could stimulate nitrate production. It is possible that the nitrification process may be performed as autotrophic nitrification in this forest. Autotrophic nitrifiers are forced aerobes and obtain their $\mathrm{C}$ from $\mathrm{CO}_{2}$ or carbonates, rather than soil organic matter (Robertson and Groffman 2007). A superficial position of the community nitrifiers could give them access to the atmospheric $\mathrm{CO}_{2}$. An autotrophic nitrification would imply access to ammonium generated by $\mathrm{N}$ inputs through an atmospheric deposition processes. Ammonium in soil solution is a ionized form of ammonia $\left(\mathrm{NH}_{3}\right)$ and a great source of substrate to autotrophic nitrification (Robertson and Groffman 2007). Given that solar energy is one of the main factors of water evaporation, the movements of soil surface water in the urban forest could play an important role in the conservation or loss of inorganic $\mathrm{N}$ at the soil surface. Soil water availability is an important factor in soil nitrification and $\mathrm{N}$ mineralization processes (Linn and Doran 1984), specifically the ammonium oxidation linked to water concentration in soil pore spaces (McGill 2007). In addition, there are processes of $\mathrm{NH}_{3}$ deposition and volatilization into and from the soil solution in response to the difference in vapor pressure between the solution and ambient air (Mosier 2008). It is possible that processes of $\mathrm{NH}_{3}$ deposition and volatilization at soil superficial level may be linked with an autotrophic nitrifier community in the soil urban forest, but further research is needed.

VPD was also positively correlated with nitrate production in urban forest. This was related to a lower SWC in this forest, as well as greater potential and real evapotranspiration (Dominguez-Eusebio et al. 2019). Smaller SWC values in the urban forest were also related to greater VPD, since it is a force that drives the movement of water in the soil-plant-atmosphere system (Rawson et al. 1977; Yuan et al. 2019). The relationship of $\mathrm{NO}_{3}$ to atmospheric variables (such as VPD) suggests that the urban forest could be susceptible to the deposition of some components suspended in the air. Especially the atmospheric $\mathrm{NH}_{3}$, of which much higher concentrations have been reported in cities compared to relatively pristine environment (Mosier 2008). Thus could affect vegetation growth, productivity, tolerance to drought and frost, and response to herbivores (Krupa 2003). It should be noted that the increase in atmospheric $\mathrm{NH}_{3}$ has been related to anthropic activities so urban forests could be strongly influenced by surrounding human activities (Vitousek et al. 1997). It is known that the biogeochemistry of urban forests is strongly influenced by the urban environment (Michopoulos 2011).

It is not common to observe a relationship between inorganic N and VPD in forest soils, but in agricultural soils or with burning of biomass and fossil fuels. A portion of the $\mathrm{N}$ contained in plant biomass or fossil fuels is converted to $\mathrm{NH}_{3}$ and emitted to the atmosphere (Mosier 2008). Such relationship can also be observed in soils influenced by domestic or wild animal excreta and crops with decomposing organic waste (Mosier 2008). It has been estimated that domestic animal excreta contribute at least with $21.6 \mathrm{Tg}$ of $\mathrm{N}$ to global ammonia emissions, synthetic fertilizers with $9 \mathrm{Tg}$ of $\mathrm{N}$, plant biomass burning or plant residues decomposition with $5.9 \mathrm{Tg}$ of $\mathrm{N}$, and burning fossil fuels with at least $0.1 \mathrm{Tg}$ of $\mathrm{N}$ (Mosier 2008). Our results suggest that human activities such pet transit, conglomerations of wild animals in the city that spend the night in the forest, in addition to those related to the plant residues and fossil fuels burning, may be influencing the inorganic $\mathrm{N}$ dynamic in this urban forest. 


\section{NH4: NO3 ratio as a trace of soil inorganic N dynamic in urban ecosystems}

Similar to three oak forests and one desert in North America, the tropical cloud forest showed higher $\mathrm{NO}_{3}$ concentrations in the urban forest compared to the rural forest. Both forests presented higher $\mathrm{NO}_{3}$ concentration than temperate ecosystems (Table 3).

Table 3

Urban and rural forest comparison in soil inorganic $\mathrm{N}$ concentration. Data showed are from: ${ }^{*}$ Goldman et

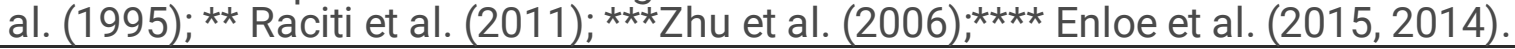

\begin{tabular}{|c|c|c|c|c|c|c|c|}
\hline Latitude & $\begin{array}{l}\text { Dominated } \\
\text { Vegetation }\end{array}$ & Site & Status & $\mathrm{NO}_{3}$ & $\mathrm{NH}_{4}$ & $\mathrm{NH}_{4}: \mathrm{NO}_{3}$ & $\mathrm{pH}$ \\
\hline \multirow[t]{2}{*}{$40^{\circ}$} & Oak & $\begin{array}{l}\text { New York, } \\
\text { USA* }\end{array}$ & Urban & ${ }_{1}^{1.3 \mathrm{mgkg}^{-}}$ & $\begin{array}{l}11.7 \\
\mathrm{mgkg}^{-1}\end{array}$ & 9.0 & 4.6 \\
\hline & & & Rural & $\begin{array}{l}0.6 \mathrm{mgkg}^{-} \\
-\end{array}$ & $\begin{array}{l}19.4 \\
\mathrm{mgkg}^{-1}\end{array}$ & 32.3 & 4.7 \\
\hline \multirow[t]{2}{*}{$39^{\circ}$} & Tulip-Oaks & $\begin{array}{l}\text { Maryland, } \\
\text { USA } A^{\star \star}\end{array}$ & Urban & $3.8 \mathrm{~g} \mathrm{~m}^{-2}$ & $\begin{array}{l}3.5 \mathrm{~g} \mathrm{~m}^{-} \\
2\end{array}$ & 0.92 & - \\
\hline & & & Rural & $0.7 \mathrm{~g} \mathrm{~m}^{-2}$ & $\begin{array}{l}8.1 \mathrm{~g} \mathrm{~m}^{-} \\
-\end{array}$ & 11.6 & - \\
\hline \multirow[t]{2}{*}{$33^{\circ}$} & Scrubland & $\begin{array}{l}\text { Arizona, } \\
\text { USA }{ }^{\star \star \star}\end{array}$ & Urban & $\begin{array}{l}6.18 \\
\mathrm{mgkg}^{-1}\end{array}$ & $\begin{array}{l}2.17 \\
\mathrm{mgkg}^{-1}\end{array}$ & 0.35 & - \\
\hline & & & Rural & $\begin{array}{l}4.1 \mathrm{mgkg}^{-} \\
-\end{array}$ & $\begin{array}{l}1.89 \\
\mathrm{mgkg}^{-1}\end{array}$ & 0.46 & - \\
\hline \multirow[t]{2}{*}{$29^{\circ}$} & Oak-Pine & $\begin{array}{l}\text { Florida, } \\
\text { USA }{ }^{\star \star \star \star}\end{array}$ & Urban & $\begin{array}{l}113.05 \mathrm{~g} \\
\mathrm{ha}^{-1} \mathrm{~d}^{-1}\end{array}$ & $\begin{array}{l}66.3 \mathrm{~g} \\
\mathrm{ha}^{-1} \mathrm{~d}^{-1}\end{array}$ & 0.57 & 3.8 \\
\hline & & & Rural & $\begin{array}{l}16.3 \mathrm{~g} \mathrm{ha}^{-} \\
{ }^{1} \mathrm{~d}^{-1}\end{array}$ & $\begin{array}{l}67.3 \mathrm{~g} \\
\mathrm{ha}^{-1} \mathrm{~d}^{-1}\end{array}$ & 4.12 & 3.5 \\
\hline \multirow[t]{2}{*}{$19^{\circ}$} & $\begin{array}{l}\text { Montane cloud } \\
\text { forest (This study) }\end{array}$ & $\begin{array}{l}\text { Veracruz, } \\
\text { Mexico }\end{array}$ & Urban & $\begin{array}{l}28.3 \mathrm{mg} \\
\mathrm{g}^{-1}\end{array}$ & $\begin{array}{l}10.8 \mathrm{mg} \\
\mathrm{g}^{-1}\end{array}$ & 0.7 & 5.8 \\
\hline & & & Rural & $\begin{array}{l}20.4 \mathrm{mg} \\
\mathrm{g}^{-1}\end{array}$ & $\begin{array}{l}38.4 \mathrm{mg} \\
\mathrm{g}^{-1}\end{array}$ & 2.9 & 4.5 \\
\hline
\end{tabular}

Soil nitrate can be a direct source of atmospheric gases and water pollutant $\left(\mathrm{NO}_{x}\right.$ and $\left.\mathrm{N}_{2} \mathrm{O}\right)$ by denitrification or leaching (Robertson and Groffman 2007). Since nitrate is more mobile and soluble than ammonium, it can be easily transported out of the root zone when precipitation exceeds 
evapotranspiration (Robertson and Groffman 2007). On the other hand, the ammonium concentration, being the reduced form of $\mathrm{N}$, gives us valuable information about soil $\mathrm{N}$ conservation due to its lower mobility and solubility, and higher energy storage capacity. We showed that the urban forest had lower soil ammonium concentration in contrast to the rural forest. This was similar to the soil $\mathrm{N}$ concentration pattern for urban and rural forests in more temperate ecosystems (Table 4). According to the $\mathrm{NH}_{4}: \mathrm{NO}_{3}$ ratio, it can be observed that great soil $\mathrm{N}$ conservation occurs in temperate soils followed by tropical and subtropical soils, but in deserts less ammonium conservation in rural than in urban soil is observed (Table 3).

Seasonal ammonium and nitrate patterns showed a peak in the nitrate concentration for the urban forest in June and in the ammonium concentration for the rural forest in August (Fig. 5). Both months correspond to high precipitation, temperature and the growing season in the study area. Monitoring stoichiometric patterns of soil $\mathrm{NH}_{4}: \mathrm{NO}_{3}$ ratio could help us to generate public urban health policies and could give us clues about the energy stored in these ecosystems.

\section{Soil $\mathbf{N}$ losses in urban forests: Challenges for the urban ecology in $\mathbf{N}$ cycle studies}

According to Kaye et al. (2006) it is important to know urban biogeochemistry, among other things, in order to know whether ecological knowledge developed in natural systems can explain the environment where humans live, and the relationship between urbanization and functioning of ecosystems structure. If urban and non-urban ecosystems are working in a similar way, then urban ecology results in an extension of existing ecological theory. However, if they are fundamentally different, then the urban research has the potential to enrich the field of ecology with new theoretical advances (Kaye et al. 2006). In our case, soil inorganic dynamics in the urban forest suggest a different biogeochemical model from that of the rural forest.

A challenge for tropical urban forests function as the one studied here is to know the mechanisms and microclimatic conditions of the system in terms of $\mathrm{N}$ losses by volatilization of $\mathrm{NH}_{3}$ and denitrification processes. From an ecosystem management perspective, denitrification is advantageous when it is desirable to remove excess $\mathrm{NO}_{3}$ from soil prior to its movement to the ground and water bodies or surface waters (Robertson and Groffman 2007). However, the denitrification process can lead to soil acidification (Robertson and Groffman 2007) so, depending on soil pH, they could be vulnerable if the soil is already acidic as in the case of tropical and subtropical urban forests (Table 3). In the case of ammonia volatilization, when the soil does not have enough adsorption capacity to retain ammonium, ammonia is not fixed and returned to the atmosphere by volatilization. In contrast, when there is enough fixed ammonium in soil solution, the ammonia is not volatilized (Mosier 2008). Physically attached to soil particles, ammonium that originates from ammonia deposition fixes ammonia and controls ammonia volatilization (Mosier 2008). Soil organic material influences this process by regulating the soil structure and adsorption capacity of soil clays (Mosier 2008). 
Our results suggest a strong functional role of the soil-atmosphere system in the biogeochemistry of the urban forest studied. Understanding the soil-plant-atmosphere system in urban environments could help us to understand the dynamics of soil inorganic $\mathrm{N}$ and its effect on the microbial and plant community. Specifically, VPD seems to play an important role in this functioning. It has been shown that plant nutrient uptake by some species is affected by the rate of transpiration, which could be limited by the VPD (Lihanvainen et al. 2016; McDonald et al. 2002; Cernusak et al. 2009; Shrestha et al. 2015; Plhák 2011). Increases in the VPD will affect vegetation growth and mortality, and the relationship between vegetation and $\mathrm{N}$ losses. The VPD and water movements in the soil-plant-atmosphere system could be another challenge for $\mathrm{N}$ cycle studies in urban ecology (Yuan et al. 2019).

\section{Conclusions}

Micro-climatic variables such as soil surface temperature conditions, air vapor pressure, and vapor pressure deficit, which are directly related to evapotranspiration, were associated with soil inorganic $\mathrm{N}$ concentration in the soil of the urban forest. However, temperature at $15 \mathrm{~cm}$ depth was associated with the concentration of soil inorganic $\mathrm{N}$ in the rural forest. The plant-soil system seems to have greater relevance in the soil inorganic $\mathrm{N}$ dynamic of the rural forest. In contrast, feedback processes aboveground suggest greater relevance of the soil-atmosphere system in soil inorganic $\mathrm{N}$ dynamics in the urban forest.

Differences in the ratio of NH4:NO3 between urban and rural forests have several important implications. First, its value may result from processes in the soil that sustains conservation of $\mathrm{N}$ (high value of $\mathrm{NH} 4$ : NO3 ratio) or losses of N (low value of NH4: NO3 ratio) in the system. Second, it can be an indicator of the importance of microbial activity that transforms $\mathrm{N}$ in the soil (autotrophic nitrification or heterotrophic nitrification). And third, it can be easily measured and monitored to in order to track the changes in the dynamics of inorganic $\mathrm{N}$. The NH4:NO3 ratio of our urban mountain cloud forest suggests high atmospheric inputs of inorganic $\mathrm{N}$ via deposition, and also large losses via $\mathrm{NO}_{3}$ by leaching. On the other hand, for our rural forest this ratio suggests a high potential for soil $\mathrm{N}$ conservation in form of $\mathrm{NH}_{4}$.

In a world with increasing urbanization, urban biogeochemistry could give us clues to better understand the mechanisms of energy and matter exchange in the conservation of $\mathrm{N}$, and how different it is from the biogeochemistry of undisturbed systems.

\section{Declarations}

Not applicable.

\section{Ethics approval, consent to participate and consent for publication}

All authors declare our ethical approval and consent to participate in the research and publication of the manuscript.

\section{Availability of data and material}


We also declare our consent to the availability of data and materials.

\section{Funding}

Our funding source was CONACYT (Mexican National Council for Science and Technology) through postdoctoral scholarship (No. 740977) obtained by CADE. We mention our funding source in the acknowledgments section.

\section{Conflicts of interest/Competing interests}

We have no competing interests.

\section{Authors' contributions}

All authors contributed to the conception and design of the study, planned the questions, objectives and analysis of the work. CADE performed the preparation of materials and data collection, carried out the analyses and wrote the first draft of the manuscript. OLB and YP reviewed and provided feedback on the manuscript in its final version. All authors read and approved the final version of the manuscript.

\section{Acknowledgements}

We thank Adalberto Tejeda of the Facultad de Instrumentación en la Universidad Veracruzana (UV) for his invaluable support for this work, to the boards of the Ecological Park Cerro de Macuiltépetl and Ayuntamiento Municipal de Xalapa, Veracruz, for the permits for the collection of soil. Funding was provided by CONACYT (Mexican National Council of Science and Technology) through postdoctoral scholarship (No. 740977) obtained by CADE. We also thank M.C. Sandra Rocha Ortiz, M.C. Lourdes Cruz Huerta and Ninfa Portilla Loeza for their support in the determination of soil analyses. We thank the support of Instituto de Biotecnología y Ecología Aplicada and Facultad de Instrumentación of UV, and INECOL.

\section{References}

Abbasi H, Vasileva V, Lu X (2017) The Influence of the Ratio of Nitrate to Ammonium Nitrogen on Nitrogen Removal in the Economical Growth of Vegetation in Hybrid Constructed Wetlands. Environments 4:24. https://doi.org/10.3390/environments 4010024

Adler FR, Tanner CJ (2013) Urban Ecosystems: Ecological Principles for the Built Environment. Cambridge University Press, Cambridge

Alan-Ellis E, Martínez-Bello M (2010) Vegetación y uso de suelo. In: Florescano E, Ortíz-Escamilla O (eds) Atlas del patrimonio natural, histórico y cultural de Veracruz. Gobierno del Estado de Veracruz y Universidad Veracruzana, pp 203-226 
Bardgett RD, Bowman WD, Kaufmann R, Schmidt SK (2005) A temporal approach to linking aboveground and belowground ecology. Trends Ecol Evol 20:634-641. https://doi.org/10.1016/j.tree.2005.08.005

Borgnakke C, Sonntag R (2013) Fundamentals of Thermodinamics. John Wiley \& Sons, Inc., USA

Bray TH, Kurtz LT (1945) Determination of total, organic and available forma of phosphorus in soil. Soil Sci 59:39-46. 10.1097/00010694-194501000-00006

Bubb P, May IA, Miles L, Sayer J (2004) Cloud forest agenda. UNEP-WCMC, Cambridge

Castillo-Campos G (1991) Vegetación y flora del Municipio de Xalapa. Xalapa, Veracruz, México. Instituto de Ecología A.C. Xalapa, Mex

Cernusak LA, Winter K, Turner BL (2009) Plant $\delta 15 \mathrm{~N}$ correlates with the transpiration efficiency of nitrogen acquisition in tropical trees. Plant Physiology 151:1667-1676.

https://doi.org/10.1104/pp.109.145870

Chapin FS, Matson PA, Mooney HA (2011) Principles of terrestrial ecosystem ecology. Springer, New York Comisión Nacional para el Conocimiento y Uso de la Biodiversidad (CONABIO) (2020) Portal de geoinformación. URL: http://www.conabio.gob.mx/informacion/gis/? vns=gis_root/clima/rsolar/rsv16mpgw. Accessed 20 November 2020

Crawley MJ (2013) The R book, Second edition. Wiley, Chichester, West Sussex, United Kingdom Domínguez-Eusebio CA, Alarcón E, Briones OL, Pineda-López M del R, Perroni Y (2019) Surface energy exchange: Urban and rural forest comparison in a tropical montane cloud forest. Urban Forestry \& Urban Greening 41:201-210. https://doi.org/10.1016/j.ufug.2019.03.018.

Emmett BA, Boxman D, Bredemeier M, Gundersen P, Kjonaas OJ, Moldan F et al (1998). Predicting the effects of atmospheric nitrogen deposition in conifer stands: Evidence from the NITREX ecosystem-scale experiments. Ecosystems 1:352-360. DOI: 10.1007/s100219900029

Enloe HA (2014) Impact of urbanization on biogeochemical cycling in western Florida. Dissertation, University of Auburn

Enloe HA, Lockaby BG, Zipperer WC, Somers GL (2015) Urbanization effects on soil nitrogen transformations and microbial biomass in the subtropics. Urban Ecosyst 18:963-976. https://doi.org/10.1007/s11252-015-0462-8. DOI 10.1007/s11252-015-0462-8

Goldman MB, Groffman PM, Pouyat RV, McDonnell MJ, Pickett ST (1995) CH4 uptake and N availability in forest soils along an urban to rural gradient. Soil Biol Biochem 27:281-286. https://doi.org/10.1016/0038-0717(94)00185-4 
Goverment of State of Veracruz (2020) Protected Natural Areas. URL:

http://www.veracruz.gob.mx/medioambiente/espacios-naturales-protegidas/ Accessed 15 June 2020

Grimm NB, Faeth SH, Golubiewski NE, Redman CL, Wu J, Bai X, Briggs JM (2008) Global Change and the Ecology of Cities. Science 319:756-760. https://doi.org/10.1126/science.1150195

Gutschick VP (1981) Evolved strategies in nitrogen acquisition by plants. Am Nat 118:607-637. https://www.jstor.org/stable/2460604

Hughes S, Grant H, Ostle N, Emmett BA et al (2004) The controls on immobilisation of ammonium and nitrate and the link to the onset of $\mathrm{N}$ saturation. In: Emmett BA, McShane $\mathrm{G}$ (eds) Terrestrial Umbrella Final Report May 2004, NERC-DEFRA Terres- trial Umbrella Contract Number EPG 1/3/186, pp 321-329

Kaye J, Groffman P, Grimm N, Baker L, Pouyat R (2006) A distinct urban biogeochemistry?. Trends Ecol Evol 21:192-199. https://doi.org/10.1016/j.tree.2005.12.006

Lavelle P, Berhe AA (2005) Nutrient Cycling. Ecosystems and Human Well-Being: Current State and Trends: Findings of the Condition and Trends Working Group, Island Press, USA

Lihavainen J, Ahonen V, Keski-Saari S, Kontunen-Soppela S, Oksanen E, Keinen M (2016) Low vapour pressure deficit affects nitrogen nutrition and foliar metabolites in silver birch. J Exp Bot 67: 4353-4365. https://doi.org/10.1093/jxb/erw218

Linn DM, Doran JW (1984) Effect of water-filled pore space on CO2 and N2O production in tilled and nontilled soils. Soil Sci. Soc. Am. J. 48:1267-1272.

https://doi.org/10.2136/sssaj1984.03615995004800060013x

Maynard DG, Kalra YP (1993) Nitrate and Exchangeable Ammonium Nitrogen. In: Carter MR (ed) Soil Sampling and Methods of Analysis, Lewis Publishers, Boca Raton, pp 25-38

McDonald EP, Erickson JE, Kruger EL (2002) Can decreased transpiration limit plant nitrogen acquisition in elevated CO2? Funct Plant Biol 29:1115-1120. https://DOI: 10.1071/FP02007

McGill WB (2007) The physiology and biochemistry of soil organisms. In: Paul E (ed) Soil microbiology, ecology and biochemistry. Third Edition. Elsevier Academic Press, pp 231- 256

Meteorological National Service (2020) Normales Climatológicas por estado. URL https://smn.conagua.gob.mx/es/climatologia/informacion-climatologica/normales-climatologicas-porestado. Accessed 17 January 2020

Michopoulos P (2011) Biogeochemistry of urban forest. Forest Hydrology and Biogeochemistry. In: Ecological Studies 216. Springer, pp 341-353

Montgomery DC (2013) Desing and analysis of experiments. Eighth Ed. John Wiley \& Sons, Inc., USA 
Mosier AR (2008) Exchange of gaseous nitrogen compounds between terrestrial systems and the atmosphere. In: Hatfield JL, Follett RF (eds). Nitrogen in the environment: sources, problems, and management. Elsevier Inc., pp 443-462

Pavao-Zuckerman MA (2008) The Nature of Urban Soils and Their Role in Ecological Restoration in Cities. Restoration Ecology 16:642-649. https://doi.org/10.1111/j.1526-100X.2008.00486.x

Pavao-Zuckerman MA, Coleman DC (2005) Decomposition of chestnut oak (Quercus prinus) leaves and nitrogen mineralization in an urban environment. Biol Fertil Soils 41:343-349.

https://doi.org/10.1007/s00374-005-0841-z

Plhák F (2011) Nitrogen supply through breathing mass flow can limit nitrogen nutrition of plants. Plant Soil Environ 49:473-479. https://doi.org/10.17221/4159-PSE

Pouyat RV, Pataki DE, Belt KT, Groffman PM, Hom J, Band LE (2007) Effects of urban land-use change on biogeochemical cycles. In: Canadell JG, Pataki D, Pitelka L (eds) Terrestrial Ecosystems in a Changing World. The IGBP Series, Springer-Verlag, Berlin Heidelberg

R Core Team (2020) R: A language and environment for statistical computing. R Foundation for Statistical Computing,Vienna, Austria. URL https://www.R-project.org/.

Raciti SM, Groffman PM, Jenkins JC, Pouyat RV, Fahey TJ, Pickett STA, Cadenasso ML (2011) Nitrate production and availability in residential soils. Ecol Appl 21: 2357-2366. https://doi.org/10.1890/102009.1

Rawson HM, Begg JE, Woodward RG (1977) The effect of atmospheric humidity on photosynthesis, transpiration and water use efficiency of leaves of several plant species. Planta 134:5-10. https://doi.org/10.1007/BF00390086

Recous S, Mary B, Faurie G (1990) Microbial immobilization of ammonium and nitrate in cultivated soils. Soil Biol Biochem 22:913-922. https://doi.org/10.1016/0038-0717(90)90129-N

Robertson GP, Groffman PM (2007) Nitrogen transformation. In: Paul E (ed) Soil microbiology, ecology and biochemistry. Third Edition. Elsevier Academic Press, pp 341- 364

Ruiz-Barradas A, Tejeda-Martínez A, Miranda-Alonso S, Flores-Zamudio RH (2010) Climatología. In: Florescano E, Ortíz-Escamilla O (eds) Atlas del patrimonio natural, histórico y cultural de Veracruz. Gobierno del Estado de Veracruz y Universidad Veracruzana, pp 203-226

Schlesinger WH, Bernhardt E (2013) Biogeochemistry: an analysis of global change. $4^{\text {th }}$ edition, Elsevier, USA.

Shrestha RK, Engel K, Becker M (2015) Effect of breathing on iron uptake and translocation in lowland rice. J Soil Sci Plant Nutr 178:365-369. https://doi.org/10.1002/jpln.201400361 
Smith P, Cotrufo MF, Rumpel C, Paustian K, Kuikman PJ, Elliott JA, et al (2015) Biogeochemical cycles and biodiversity as key drivers of ecosystem services provided by soils. SOIL 1:665-685.

https://doi.org/10.5194/soil-1-665-2015

Sollins P, Glassman C, Paul EA, Swanston C, Lajtha K, Heil JW, Elliot ET (1999) Soil carbon and nitrogen: pools and fractions, In: Robertson GP, Coleman DC, Bledsoe CS, Sollins P (eds.) Standard soil methods for long-term ecological research. Oxford University Press, Inc., pp 89-105

Trammell TLE, Tripler CE, Carper SC, Carreiro MM (2017) Potential nitrogen mineralization responses of urban and rural forest soils to elevated temperature in Louisville, KY. Urban Ecosyst 20:77-86. https://doi.org/10.1007/s11252-016-0580-y

Vitousek P, Howarth R (1991) Nitrogen limitation on land and in the sea: How can it occur?. Biogeochemistry 13:87-115. https://doi.org/10.1007/BF00002772

Vitousek PM, Aber J, Howarth RW, Likens GE, Matson PA, Schindler DW, Schlesinger WH, Tilman DG (1997) Human alteration of the global nitrogen cycle: causes and consequences. Ecology 1:1-15. https://doi.org/10.1890/1051-0761(1997)007[0737:HAOTGN]2.0.CO;2

Wolrd Bank (2020) Urban population growth. URL:

https://datos.bancomundial.org/indicator/SP.URB.GROW?locations=MX-- Accessed 18 June 2020

Yuan W, Zheng Y, Piao S, Ciais P, Lombardozzi D, Wang Y, et al (2019) Increased atmospheric vapor pressure deficit reduces global vegetation growth. Sci Adv 5, eaax1396.

https://doi.org/10.1126/sciadv.aax1396

Zhu W-X, Hope H, Gries C, Grimm NB (2006) Soil Characteristics and the Accumulation of Inorganic Nitrogen in an Arid Urban Ecosystem. Ecosystems 9:711-724. https://doi.org/10.1007/s10021-006-00781

Figures 


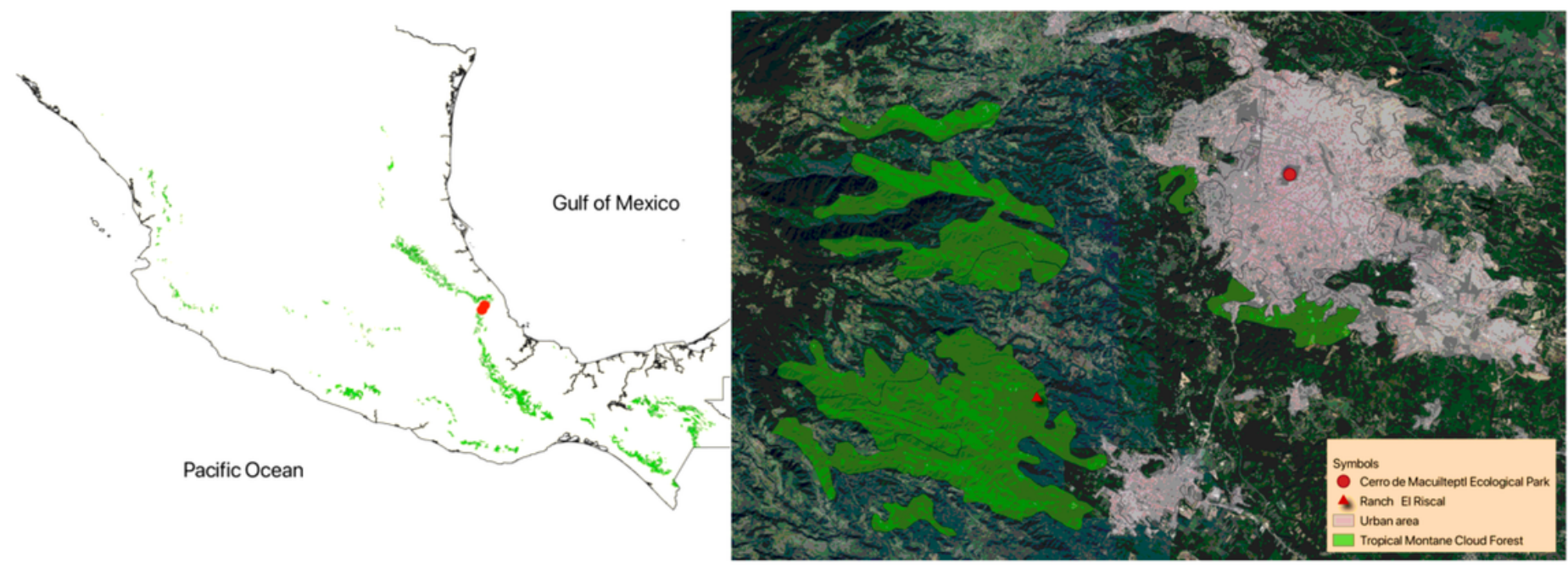

\section{Figure 1}

Distribution of the cloud forest in Mexico (Left, red dotes represent the study sites) and close up of sample sites (right). The urban forest (30 ha) is located in the center of the city of Xalapa in the state of Veracruz in Mexico. Source: CONABIO (2020). Note: The designations employed and the presentation of the material on this map do not imply the expression of any opinion whatsoever on the part of Research Square concerning the legal status of any country, territory, city or area or of its authorities, or concerning the delimitation of its frontiers or boundaries. This map has been provided by the authors.
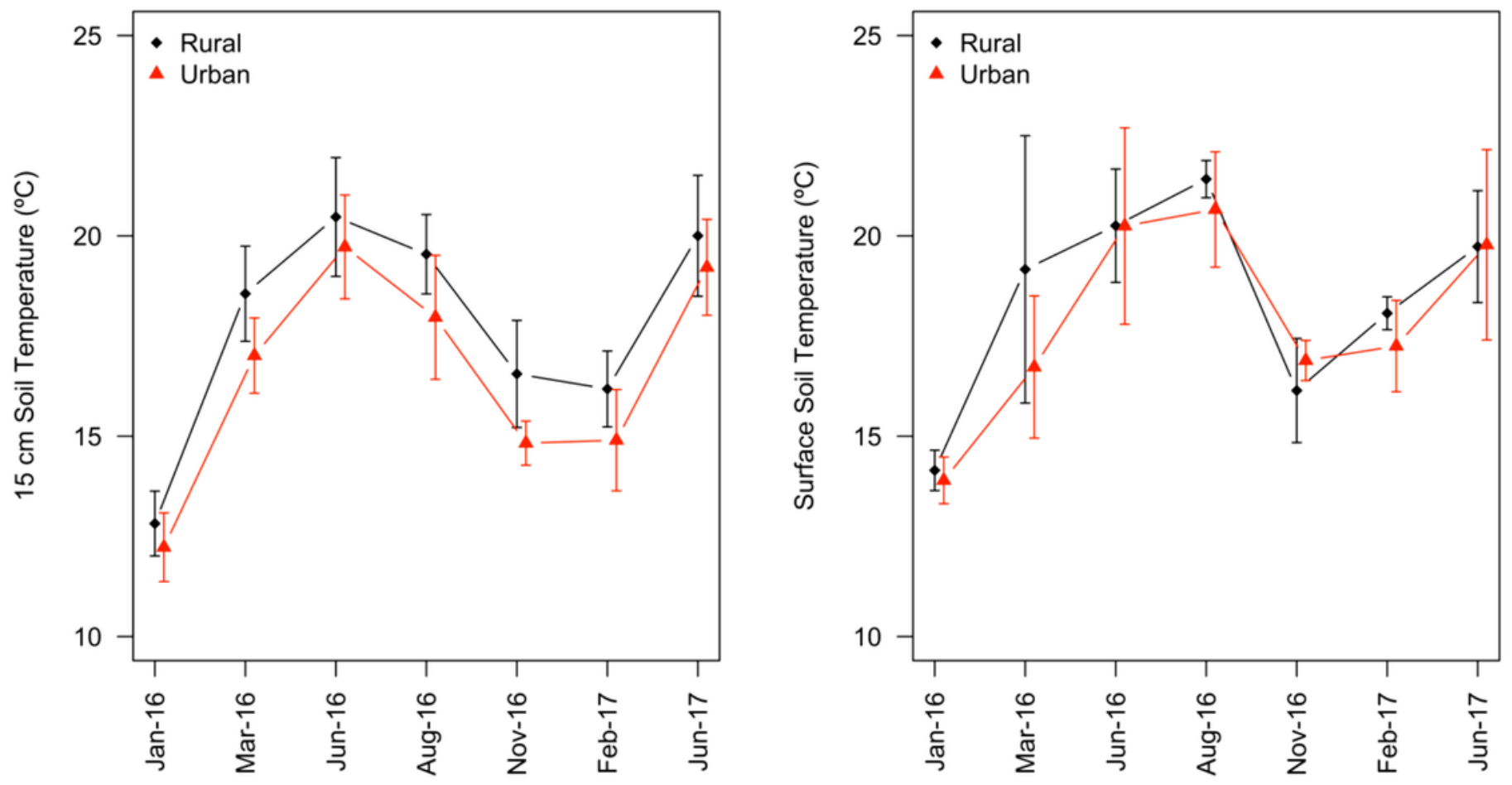

Figure 2 
Seasonal behavior of (a) surface and soil temperature at $15 \mathrm{~cm}$ depth in an urban and rural cloud forest from January 2016 to June 2017. Mean \pm 1 standard deviation are shown.

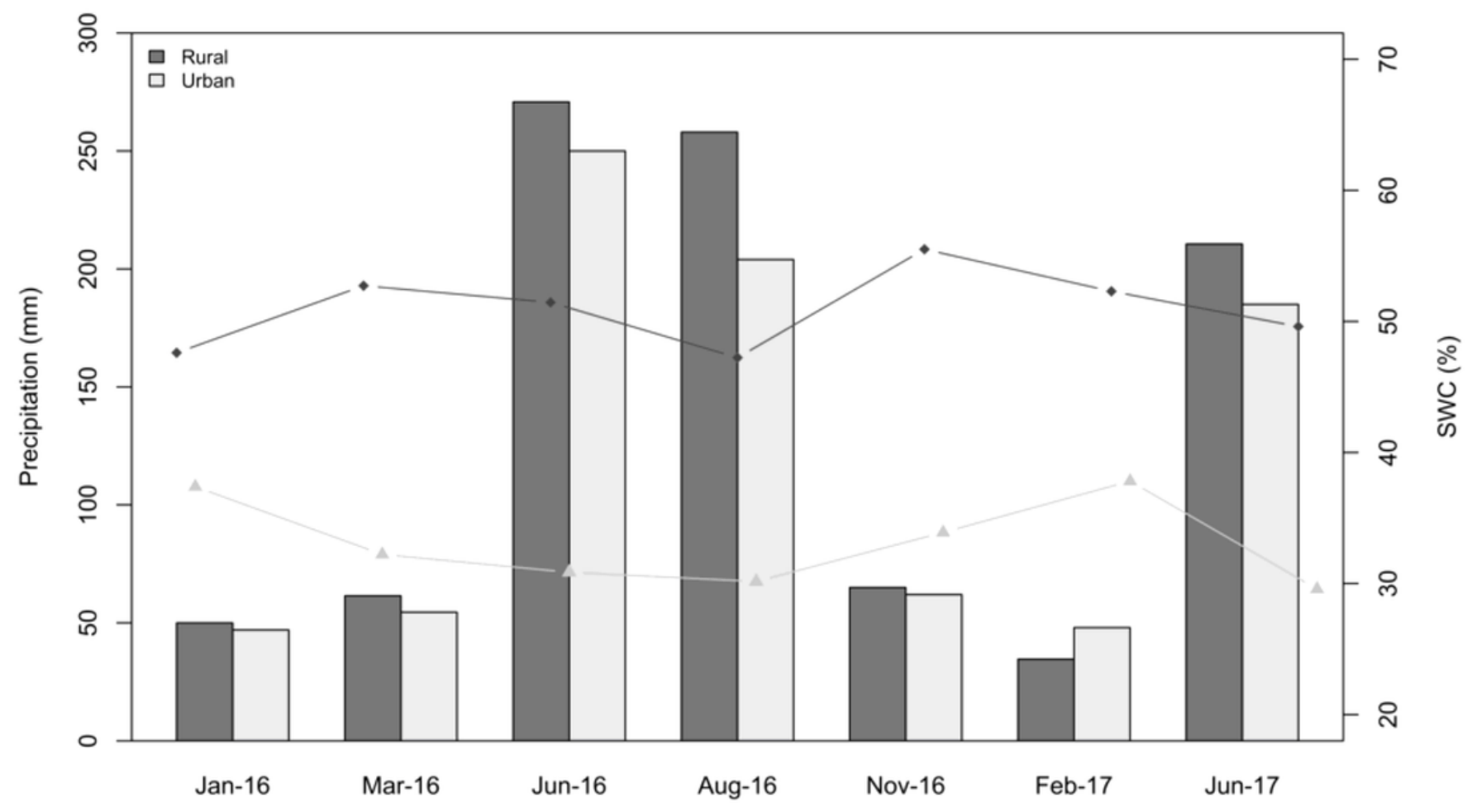

Figure 3

Seasonal behavior of precipitation and soil water content (SWC) in an urban and rural cloud forest from January 2016 to June 2017. Dark and clear bars indicate precipitation and light triangle and dark diamonds indicate SWC for the urban and rural forest. 


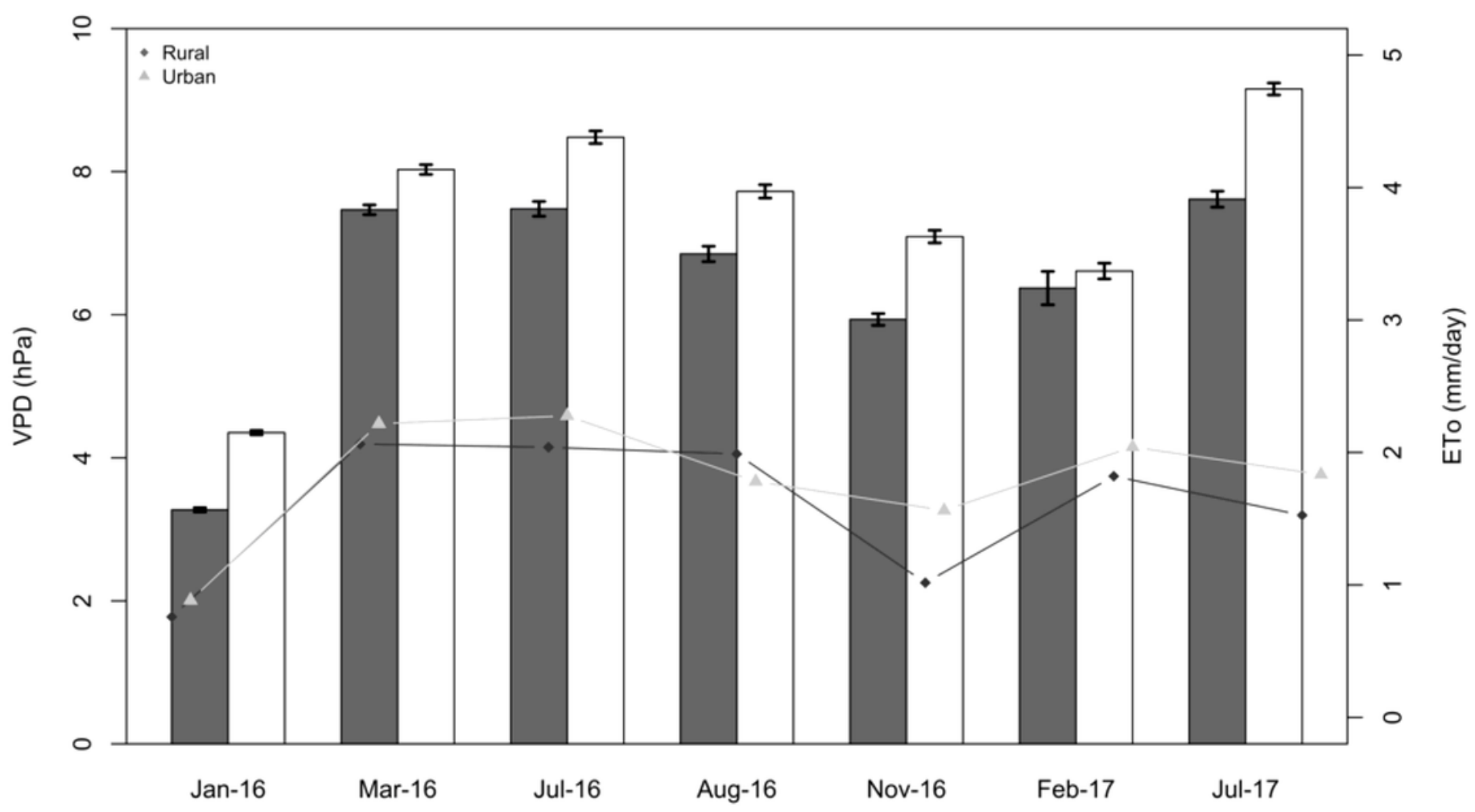

Figure 4

Seasonal potential rate of evapotranspiration (ETo) and vapor pressure deficit (VPD) in an urban and rural cloud forest from January 2016 to June 2017. Bars indicate VPD and lines indicate ETo (triangles represent the urban forest and diamonds the rural forest). Mean \pm 1 standard deviation are showed.
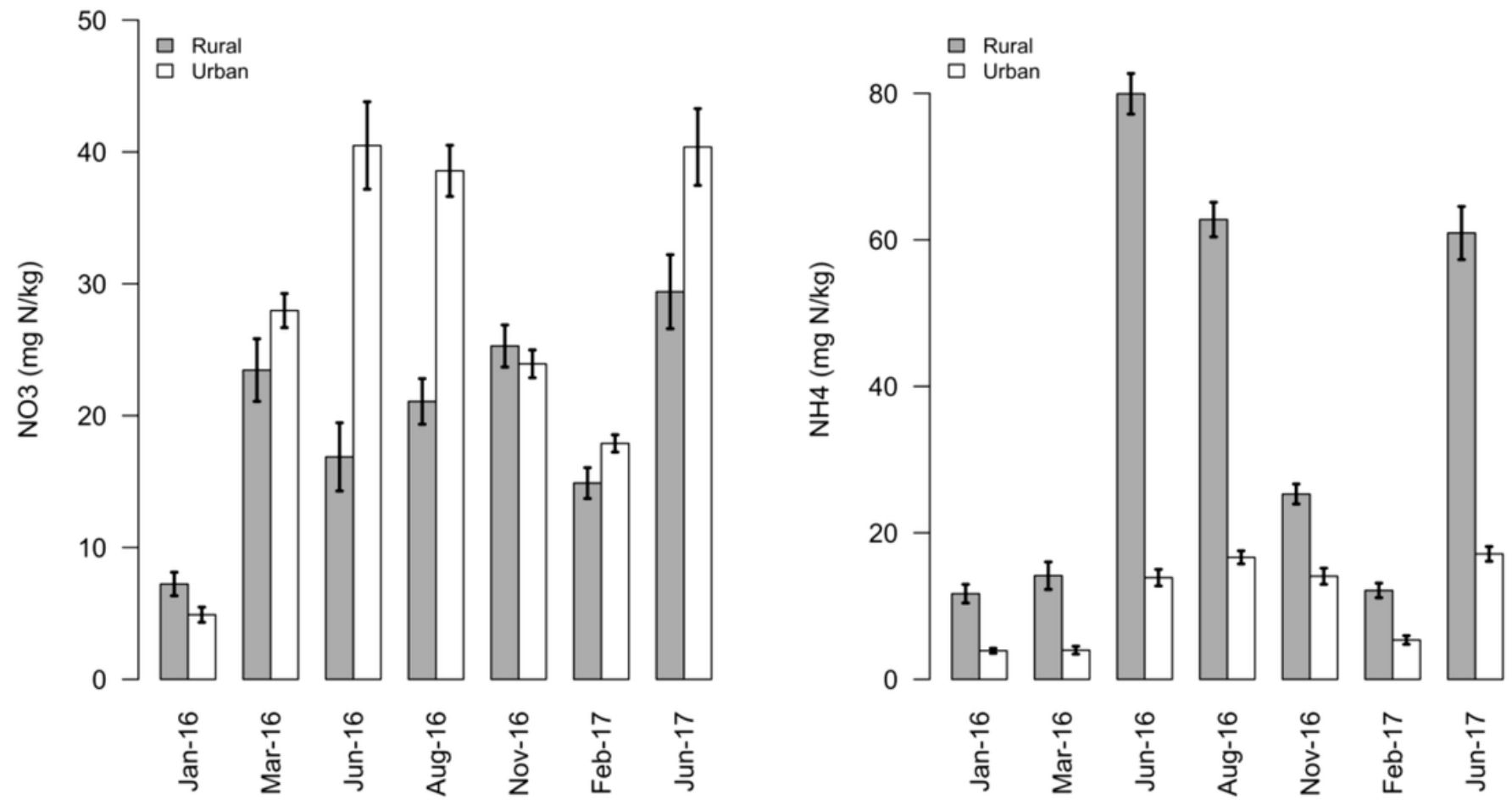
Figure 5

Seasonal behavior of soil inorganic $\mathrm{N}$ concentrations in an urban and rural cloud forest from January 2016 to June 2017. Mean \pm 1 standard deviation are shown.
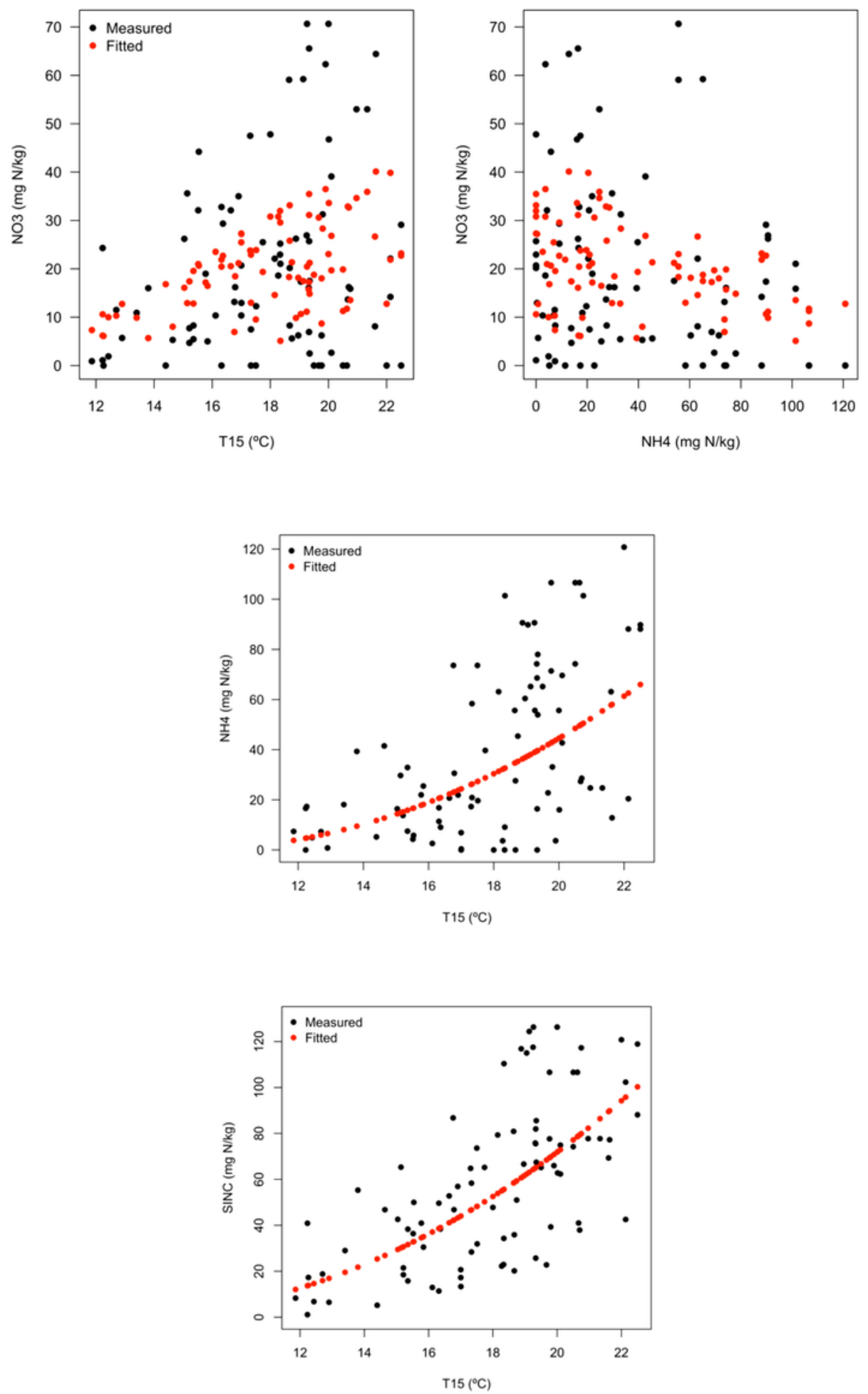

Figure 6 
Relationship between soil inorganic N, edaphic and micro-climatic conditions of the rural forest. Red points are the fitted data obtained from models (see, Table 2). NO3 = Nitrate, NH4 = Ammonium, SINC = Soil inorganic $\mathrm{N}$ concentration (NH4+NO3), T15 = Soil temperature at $15 \mathrm{~cm}$ depth.
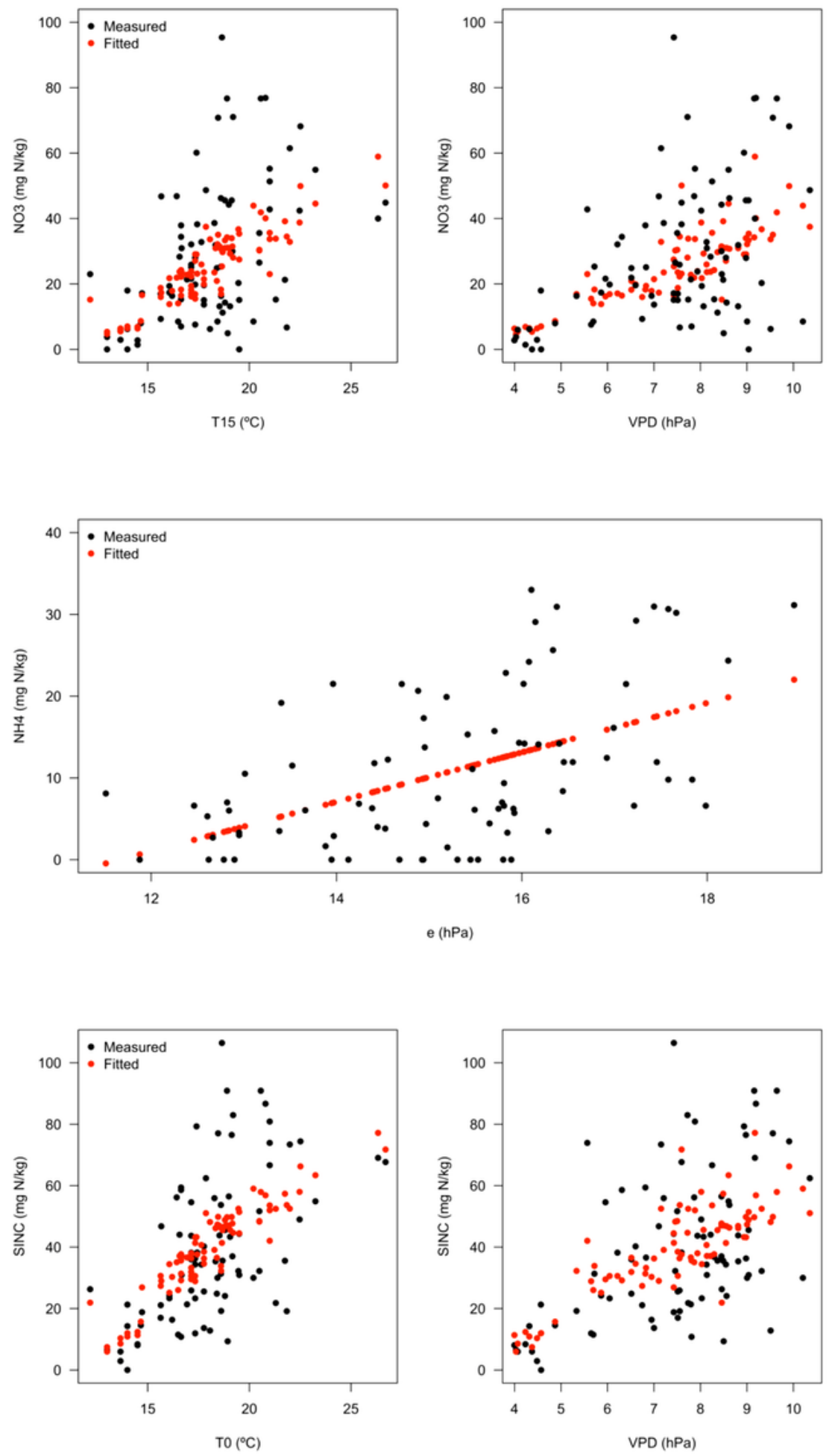

Figure 7

Relationships between soil inorganic $\mathrm{N}$ concentration, edaphic and micro-climatic conditions of the urban cloud forest. Red points are the fitted data obtained from models (see, Table 2). NO3 = Nitrate, NH4 = 
Ammonium, $\mathrm{SINC}=$ soil inorganic $\mathrm{N}$ concentration $(\mathrm{NH} 4+\mathrm{NO} 3), \mathrm{TO}=$ Surface soil temperature, $\mathrm{e}=$ Water vapor pressure, $\mathrm{VPD}=$ Vapor pressure deficit in the air.

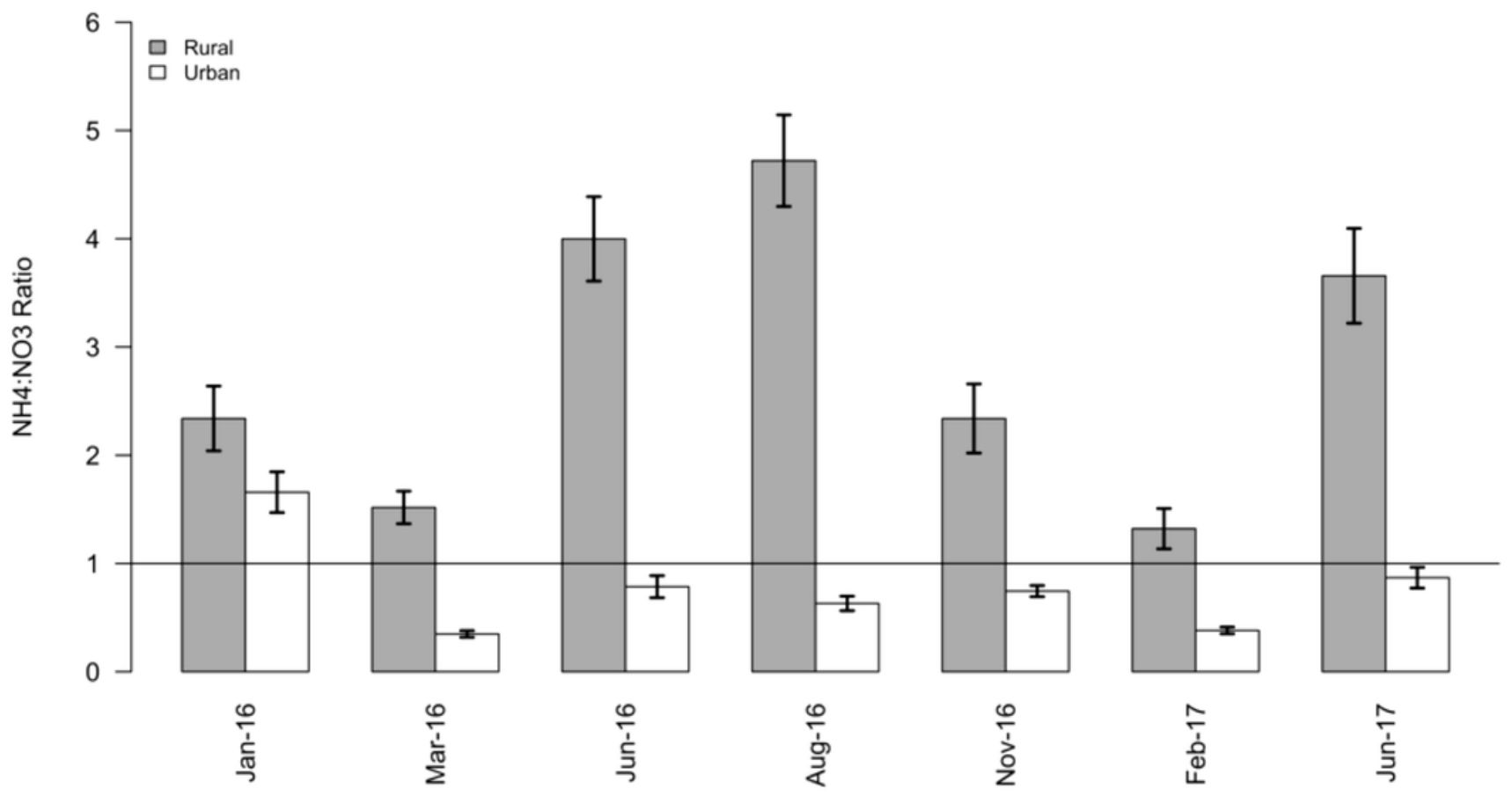

Figure 8

Seasonal pattern of the NH4:NO3 ratio in a rural (grey) and urban (white) cloud forest from January 2016 to June 2017. Mean \pm 1 standard deviation are shown. 